\title{
Innovation and Economic Growth in Emerging Latin American Countries: The Case of Mexico, Brazil and Chile
}

\author{
Edgar J. Saucedo A ${ }^{1}$, Marisol Borges $Q^{2}$ \\ ${ }^{1}$ University of Veracruz Institute of Economics and Social Studies, Mexico \\ ${ }^{2}$ University of Veracruz PhD student, Accounting and Administration Faculty, Mexico \\ Email (corresponding author): marisol borges1@ @otmail.com
}

\begin{abstract}
Over recent years, several theoretical and empirical research projects (from developed countries) have studiedinnovation as a complex process involving participation, interaction and interrelationship of actors (organizations, individuals, businesses) and institutions (government, education, research centres) as elements of a collective system that contribute and influence the innovation process. In addition, such research shows how innovation has impacted positively on the economic growth of nations.In order to understand the functioning of the National Innovation Systems in emerging countries (Mexico, Brazil and Chile), we performed a critical analysis of the approach, examining their application limitations and recognising the characteristics and interests of Latin American countries. Furthermore, we analysed the impact of innovation on economic growth in these countries. The aim of this paper is to analyse whether the differences in economic growth among Mexico, Chile and Brazil, are explained by gaps in levels of innovation.
\end{abstract}

Keywords: Innovation, Economic Growth, Latin-American

\section{Introduction}

The links between economic growth and innovation have been studied for a long time. Innovation represents a stimulus for business, because it assures monopoly income once their products enter the market, thus it seems natural that companies are involved in permanent innovation processes. However, certain conditions are necessary for countries to generate innovation. Some of the conditions are: the respect of intellectual property rights, the existence of entrepreneurs, R\&D (Research and Development) public policies, well-established national innovation systems as well as other variables.

Latin America has economic characteristics that distinguish it from other regions of the world, its high level of inequality and the fact that its markets are dominated by monopolies and oligopolies. In such a context, it is interesting to analyse what happens to the relationship of economic growth and innovation in Latin America, and specifically compare three countries with different characteristics in the region: Mexico, Brazil and Chile.

The aim of this paper is to analyse whether the differences in economic growth among Mexico, Chile and Brazil, are explained by gaps in levels of innovation. Economic growth is not only explained by innovation, there are other factors that determine it, but we want to address whether differences in economic growth correspond to the innovation gap among the selected countries.

\section{Innovation and national innovation systems}

In recent decades, innovations have been considered an engine of economic growth, this approach stems from the contributions of Joseph Schumpeter, who in 1942 opened a line of research, to provide input for the construction of a theory of economic development based on processes of innovation and technological developments (Montoya, 2004); 
basically identifies the presence of innovations in economic cycles, which are the cause of development, and therefore considers innovation as a pillar of capitalism.

The above idea created a new conceptualisation of economic theories, besides representing a major break in the existing theories, since the current neoclassical theory could not explain the presence of technical innovations in economic cycles and the dynamics of economic growth (Dossi, Friedman and Nelson, (1988)).

This context displayed the need for a new approach to economic theory, able to incorporate and explain the technological and institutional change in the mainstream economic analysis (Dossi, Friedman and Nelson, (1988)). The theory of evolutionary technological change emerged. This new paradigm, sees innovation as a complex, dynamic and evolving process that causes changes in the economy (Hanusch and Pyka, (2005),Hanusch and Pyka(2007); Dutrenit, (1994)), also reflects the importance of an institutional framework to support the process of innovation, since it involves the participation and interaction between enterprises, financial sector and institutions.

Evolutionists believe that the generation of knowledge comes mainly from the tacit and explicit knowledge, the first is rooted in intuition, is personal and difficult to communicate; the second comes from education and can be transmitted through formal language. Added to this, Dossi, Freeman and Nelson (1988) believe that innovation also comes from paths developed by the company, which will define a specific set of skills and experiences that determine the behaviour and activities of research and development to follow (Dutrenit, (2009); Acosta and Coronado, (2006)).

But what is innovation? Schumpeter (1984: 120) introduces creative destruction, which is a break with the past; replacing the old for the new; differently using the existing resources and means of production to make new combinations conceived for the introduction of a new good, a new method of production, opening a new market, the conquest of a new source of supply or the creation of a new organization. It defines what we know today as innovation.

According to the Oslo Manual (2014: 45) innovation is "the introduction of a new or significantly improved product (good or service), or process, new marketing method, or a new organisational method in business practices, workplace organization or external relations". For purposes of this investigation, innovation is understood as the introduction and adoption of a new or improved product, service, processes, business model or organisational structure.

In the beginning, innovation was understood as a linear process consisting of: the first stage (invention), specialised researchers engaged in studying the existing theoretical knowledge that will serve them as a platform for the creation of new knowledge; subsequently, at the stage of innovation, the technical application of this knowledge, that is implemented to a good or service to enter the market and subsequently spread or sold to the interested parties. However, this way of studying innovation began to be criticised from the '70s, because the innovation process is more complex; technological innovations not arising from research or basic stage; may arise at various stages and even consumers (Mulder, 2007). This highlights the need to study innovation processes under a systemic view that gives importance to companies, laboratories, research centres, public sector, institutional and organizational context for creating new combinations.

According to Freeman (1993), the vision of the National Innovation Systems (NIS) has its origin in 1841 when Friedrich List wrote that the German's leadership over Britain was due to a range of policies that protected certain sectors and drove the application of new technologies to promote industrialisation and economic development. Today, this vision has been studied by Lundvall (1992), who defines NIS as elements and relationships between agents and institutions that interact in the production, dissemination and use of new and useful knowledge, as part of a collective system, located in a given region.

According to the OECD, cited in Rincon (2004), the following definitions are considered:

1. Freeman defines NIS as: a network of public and private institutions whose activities and interactions initiate, import, modify and diffuse new technologies

2. Nelson defines NIS as: a number of institutions whose interactions determine the innovative performance of companies from one country or region.

Therefore, NIS must be understood as an interaction and interrelation between actors and institutions involved in the innovation process - development, introduction, diffusion and use of innovations - as part of a collective system 
belonging to a specific territory. Under this contextualization, innovation requires a change in the companies, organizations, universities, research centres and political and economic institutions that foster an enabling environment for generating and sharing new knowledge to create innovations and new technologies.

According to Nest (2012) the actors and institutions that make up the NIS are:

1. Direct actors: the companies, inventors, university research centres and other organisations that create and demand technologies.

2. Service providers: institutions that support the direct stakeholders, such as financial resources, access to technology to disseminate knowledge among others.

3. Promoters and policymakers: institutions that create modify and interfere with the regulatory framework of an innovation system.

\section{Innovation and economic growth}

Economic growth, in the long term, is explained by several factors: investment, human capital, the provision of public goods (by the government), respecting the rule of law, productivity, exports, strong and inclusive institutions, innovation etc. (Mankiw, Romer\& Weil (1990), Barro (1989), Feder (1983), Mahoney (2001), North (1989), Acemoglu, Johnson and Robinson (2005)).

Innovation is one of the factors which contributes to economic growth (Wong, Ho\&Autio (2005), Freeman (2002)), because there are countries such as South Korea and Israel with high innovation indicators that at the same time have the highest rates of economic growth in the world. Thus, the link between innovation and economic growth is strong (Aghion\& Griffith (2008)), and has been studied by several of the world's regions. But how is this link explained? And what are the factors that encourage innovation?

From a theoretical point of view, we can use the concept of creative destruction of Schumpeter to define innovation, so that it occurs when an invention is inserted into the market and destroys a previously dominant industry (Aghion\&Howitt (1990)). The link between economic growth and innovation is led by technological progress which in turn drives productivity.

It is important to note the difference between invention and innovation, because the first is the creation of a new product or idea without entering it into the market, while the second implies that the invention is introduced into the market. In that sense, innovations require certain conditions.

A very important element in innovation is the existence of entrepreneurs, that is, people with the ability to insert inventions into the market. On the other hand, there must be strong innovation systems and inclusive institutions to provide all the conditions for creative destruction (Acemoglu\& Robinson (2012)).

Innovation systems are not sufficient to generate innovation; there must be interaction between its elements (Lundvall (2009). Thus, the government, universities and businesses should have the links and conditions for creative destruction. Innovation generates higher incomes for companies, due to the monopoly revenues generated for a certain time by patents. When intellectual property rights are respected, companies enjoy extraordinary income for the duration of the patents.

Competition is another factor that determines the level of innovation of a country. Some authors point out that competitive markets create incentives to innovate (Aghion, Bloom, Blundell, Griffith \&Howitt (2002)), because competition induces firms to innovate in order to remain in the market, however, it is proposed that the relationship between innovation and competition is shaped like an inverted $U$, that is, when competition increases, innovation grows up to a certain point, but from that point any increase in competition reduces innovation. On the other hand, other authors consider that competition reduces the incentives to innovate (Grossman \&Helpman (1991), Romer (1990)), due to the fact that anti-trust laws reduce incomes of creative destruction. 
Our study links economic growth and innovation in three Latin American countries. The selected countries (Chile, Brazil, Mexico), like the rest of Latin America, are characterised by monopolistic or oligopolistic markets, therefore it is important to analyse the impact of the lack of competition on innovation and economic growth.

In developed countries the elements of the NIS are well-linked, but in Latin America that does not happen, because institutions of the region are not fully inclusive.We define the institutional gear as the ability of governments to strengthen the link among members of the NIS, so that the outcome of this relationship is new products entering the market. In the case of innovation, the institutional gear refers to closer links, by the capacity of national institutions which generate that inventions enter the market with relative ease.

It is important to distinguish the relationship between the actors of NIS and the institutional gear. The first concept refers to the existence of links among the actors, while the second concept refers to the fact that this link generates ideas and that these ideas reach the market. In developed countries, closer links mean more innovation, but in developing and emerging countries, links among actors of NIS do not necessarily generate more innovation, because institutions do not necessarily work as in the case of the first world countries. The institutional gear works as an enhancer of these links, because it allows the generation of conditions of trust that ultimately produce creative destruction.

Overall, economic growth is determined by innovation, but in developing countries it depends strongly on the institutional gear, competition, the entrepreneurs and respect for property rights.

\section{National innovation system}

In most Latin American and Caribbean economies NIS have been implemented gradually; having the state as a key institution, through programmes, policies and incentives that seek to create the environment and conditions to innovate and compete in national and international matters.

An example of this are the paths developed by Chile, Brazil and Mexico that have made changes in their regulatory frameworks and offered various programmes that encourage businesses, universities, research centres (among others), to develop innovation processes.

\subsection{Chile}

In this case, there have been significant efforts and incremental improvements; by strengthening institutions, policy generation, incorporating highly educated professionals and the supply of funds and programmes that promote scientific and technological development.After several years of testing and experimentation, in 2005, the "National Innovation System for Competitiveness" (NISC) was created which has contributed favourably to the development of NIS and has provided guidance for the development of policies and strategies (in the long term). However, the supply of multiple programmes supporting innovation lacked integration and systemic view (Hodara, (2006) \&Parraguez, (2009)), given that sometimes they competed with each other and there was duplicity of work. Added to this, the programmes did not prove their efficiency and profitability.

According to the report of the National Innovation Council for Competitiveness in 2006, the NISC delivered a proposed strategy on innovation and competitiveness, which has served as a guiding framework in recent governments (SistemaNacional de Innovación (2014)).Parraguez (2009) points out that the main programmes that support the innovation process are grouped into four ministers who are in institutional coordination. The description of each programme was analysed by the OECD and detected a number of weaknesses in the system:

1. Lack of a "culture of innovation" in the business sector

2. Low spending on R \& D

3. Shortage of specialised human resources

4. Many research centres with poor quality which were irrelevant

5. Few financial support mechanisms

6. Weak links between industry and universities

7. Lack of connection and insufficient cluster firms

The Chilean government took action on the matter and developed and strengthened the NIS, therefore, in 2010 within the "agenda for innovation and competitiveness 2010-2020" all programmes, proposals and improvements considered 
conducting commissions and interagency working groups, as a meeting among public, private actors, academics, civil society, incubators, companies, research centres and universities to share knowledge and generate agreements that achieve growth based on innovation and the creation of links among the main actors in the system.

However, Gobierno de Chile (2013) points out the weaknesses of Chilean companies and some policies that should be implemented: improving the quality of human capital, primarily in tertiary education and training; creating an innovative culture that encourages companies and other actors to innovate; increasing investment in R\&D, as compared with OECD countries ( $2 \%$ of GDP), because the said country spends less than $1 \%$ of GDP, and finally, creating a society that is not afraid to develop and learn new things.

\subsection{Brazil}

The Brazilian case has unique characteristics, because in recent years it has made significant efforts to build an NIS. The Brazilian government has a specific Minister in Science, Technology and Innovation who is responsible for formulating policies. In Lula's government, a new legal framework to promote innovation activities was implemented, the Lei do Bem (Law of property) and Lei da Inovacao, which established mechanisms for their financing (Cassiolato et al., (2013)).Meanwhile, investment in R\&D is greater than $1 \%$ of GDP, which comes mostly from the government and a small proportion of private agents (Jimenez et al, (2013)).This demonstrates the government's commitment to promote innovative activity, however, the Brazilian NIS has a weak systemic approach (NESst, 2012), as only $11 \%$ of the population has a higher degree, and according to the OECD (2009), cited in NESsT (2012), only 22\% of researchers are in the business system versus $80 \%$ in the United States. This overview shows that efforts are still being made in the interplay of actors.To address this environment, Brazil has used technology parks as a tool for linking universities and industry (Romero, (2013)), in 2010, the Technology Park Rio de Janeiro managed to attract 23 research centres to develop research projects (Romero, (2013)).

According to Jimenez et al. (2013), the Brazilian NIS still has room for improvement: investment in R \& D remains low and universities and research centres are the first to receive payments, forgetting the productive sector. Another element that describes Brazil's economy is the development of regional innovation systems, given that their regions are very different. On one side is the Northeast, which has lags in education, health, income and access to basic services, and on the other, an industrialised region with opposite characteristics.Therefore, it has motivated the development of specific federal programmes and policies to each region, which has prevented the development of the Brazilian system.

\subsection{Mexico}

Mexico has decided to invest in research, scientific and technological development, through the provision of programmes, funds and policies that support an NIS. While there have been significant advances in strengthening and shaping the NIS, some failures of entailment and interrelationship exist among agents which have caused it not to be developed successfully.

In 1970 the National Council of Science and Technology (CONACYT) emerged, which serves as the main institution of the state to design and implement policies for science, technology and innovation. Since 2000 the law of science and technology was created and other regulatory changes have strengthened their capacity of planning, design and implementation of public policies through the implementation of six-year programmes. These programmes establish the commitment to develop their respective laws and commissions for science and technology (Jimenez et al (2013)). However, not all programmes have progressed equally in compliance, because federal programmes function as proposals and recommendations. For its part, colleges provide highly trained individuals to generate and share knowledge; its funding comes directly from the government, which shows a weak relationship with the productive sector, preventing the generation of self-financing.

The business sector is the only agent that introduces products, processes or services to the market, but in the Mexican case it presents a particular feature; the process of industrialisation seems to have found more effective survival mechanisms (Casas, et al, (2013)) than the interaction with other agents. Of a total of 39,500 companies, only 170 were linked with research institutes and universities and collaborated to generate innovations. This has led to limited innovative activity, and demonstrates that the business sector is acting as a single agent in the NIS (Casas, et al, (2013)). 
Jimenez et al, (2013) show the disadvantages of the Mexican NIS. This author points out that there are a limited number of companies - only 2,120- involved in support programmes of CONACYT, which shows the low participation and business interest to develop innovation processes, and the weakness in the Mexican regional governments or regions derived from the environment created by the national policy on industrial development, whose origin is the use of existing resources and inexpensive labour. The development of collaborative R\&D projects are limited because universities and research centres are related to companies only for laboratory testing, technical assistance and training of qualified human capital (Jimenez et al., 2013).

\subsection{Summary: Chile, Brazil and Mexico}

In summary, the Chilean NIS has closer links among actors, development of agencies, programmes, and funds, and more cohesive and coordinated policies. Despite Brazil making significant efforts for the formation of NIS, inequality among regions has led to the implementation of specific policies and funds to develop a regional innovation system. In Mexico, progress has been made for the establishment of the NIS, however, the only actor that can introduce innovations to the market (companies) is not linked with educational institutions and research centres, and it is only related to the government for financing innovative activities. This context shows a significant break in the system and a relatively low impact on economic growth.

\section{Innovation and economic growth in Latin America}

In this section we analyse the relationship between economic growth and innovation for three countries in Latin America: Mexico, Brazil and Chile. Given that the difference in the economic growth of these countries should be explained (in part) by the level of innovation that exists in Mexico, Brazil and Chile, that is, we seek to explain the differences in economic growth through processes of creative destruction.

The selected countries have very different economies, because while the Mexican economy is focused on growth from outside, Brazil has an economy with emphasis on the domestic market, while Chile's economy is characterised by the export of commodities but with a pro-active government in the regulation of capital (Bizberg, (2015)). Thus, we believe that by using these three countries we cover the economies of Latin America.

Despite the differences among the above three countries, there are some similarities that are important to highlight when innovation is analysed. The first characteristic shared by these countries is that their economies generate inequality; in fact Latin America is considered the region with the greatest inequality in the world (Schneider, (2009)). The second feature:these three countries have monopolies and oligopolies (Schneider, (2009)).The analysis focuses on analysing the economic growth, i.e. it looks for whether there are significant differences among Mexico, Brazil and Chile. Later, we will discuss some variables that foster innovation (institutional gear) and others that are seen as products of innovation (patents and Global Innovation Index).

Figure 1 shows the economic growth of the three selected countries in different periods. The average annual growth rate of Gross Domestic Product (GDP) of Chile is higher than the rate of Mexico and Brazil in any of the periods of time, for example, if we take the whole period (1980-2014), Chile has an economic growth above $4 \%$ while economic growth in Mexico and Brazil is around 2\%. If we take the eighties, there is a reduction in economic growth in the three countries, but still Chile has the highest growth. In the early nineties, Chile registered an economic growth above $6 \%$, while Brazil and Mexico had an economic growth close to 3\%. In the early 2000s, Brazil had an acceleratedgrowth (very close to Chile, both 4\%), while Mexico grew at a rate lower than 3\%. In the period 2010-2014, Chile remains the fastest growing of the three countries, with economic growth above $4 \%$. Brazil has a positive growth trend from the eighties to the early 2000s, while the Mexican economy is stagnant with economic growth close to $2 \%$. Figure 1 shows that regardless of any time period used, Chile has higher economic growth than Brazil and Mexico. We start from the above observation to continue the analysis, so that we can look to discover if innovation explains the difference in Chilean economic growth with regard to the other two countries. 


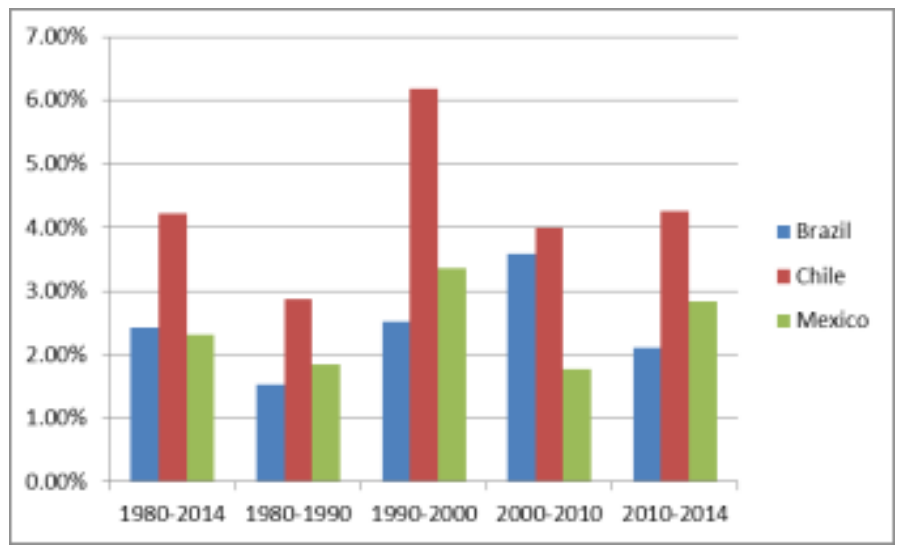

Figure 1: Average GDP growth, 1980-2014 (source: WEO (IMF)

Table 1 serves to reinforce the conclusions of Figure 1. The following table shows GDP per capita in purchasing power parity of the three selected countries. GDP per capita in Chile is higher than the Mexican and Brazilian, and the growth rate of GDP per capita in the period 1980-2014 for Chile (3.04\%) is three times higher than Brazil (0.87\%) and four times that of Mexico (0.69\%). If this trend continues, Chile will increasingly move away from Mexico and Brazil, because it has a higher GDP per capita, and has been growing at a higher rate.

Table 1: GDP per capita (PPP) and growth of GDP per capita (PPP) for selected countries

\begin{tabular}{|c|c|c|}
\hline Country & $\begin{array}{l}\text { GDP per capita } \\
\text { (PPP) } 2014\end{array}$ & $\begin{array}{l}\text { Growth GDP per capita } \\
\text { (PPP)1980-2014 }\end{array}$ \\
\hline Chile & 22,971 & $3.04 \%$ \\
\hline Mexico & 17,881 & $0.69 \%$ \\
\hline Brazil & 16,096 & $0.87 \%$ \\
\hline
\end{tabular}

Source:WEO (IMF)

To analyse the impact of innovation on economic growth differential between Chile and selected countries, we have chosen the Global Innovation Index (GII), which measures the overall level of innovation of a country. Table 2 shows that GII of Chile (40.6) is higher than GII of Brazil (36.3) and GII of Mexico (36).

Table 2: Global Innovation Index for selected countries, 2014

\begin{tabular}{|c|c|c|c|c|c|c|}
\hline & \multicolumn{2}{|c|}{ GII } & \multicolumn{2}{c|}{$\begin{array}{c}\text { Innovation input sub- } \\
\text { index }\end{array}$} & \multicolumn{2}{c|}{$\begin{array}{c}\text { Innovation output sub- } \\
\text { index }\end{array}$} \\
\hline Country & Score & Rank & Score & Rank & Score & Rank \\
\hline Chile & 40.6 & 46 & 48.4 & 37 & 32.8 & 54 \\
\hline Brazil & 36.3 & 61 & 41.7 & 63 & 30.8 & 64 \\
\hline Mexico & 36 & 66 & 42.2 & 62 & 29.9 & 70 \\
\hline
\end{tabular}

Source:Cornell University, INSEAD, \& WIPO

Table 2 also shows the input and output sub-indexes of the GII. The first sub-index is built on the necessary inputs for innovation and shows weather conditions in a country generate creative destruction, and like the GII, Chile appears in first position of the selected countries. The second subscript shows innovation products, and as in previous cases, Chile appears first. In general, we can say that the spread of Chilean economic growth with respect to Brazil and Mexico is explained to some extent by the greatest innovation of Chile.

In order to refer to institutional gear, we selected the variable University / Industry Research Collaboration (from GII), which measures research links between universities and industry. In Section 3, we noted that the institutional gear generates economic growth, because it drives creative destruction. Figure 2 shows that Chile has the highest indicator, 
Mexico then follows and finally Brazil. With the information in the following figure, it can be noted that economic growth in selected countries is related to research links between universities and industry. The institutional gear refers to institutional complementarity that generates creative destruction, either through stronger links between agents of NIS or by promoting such links.

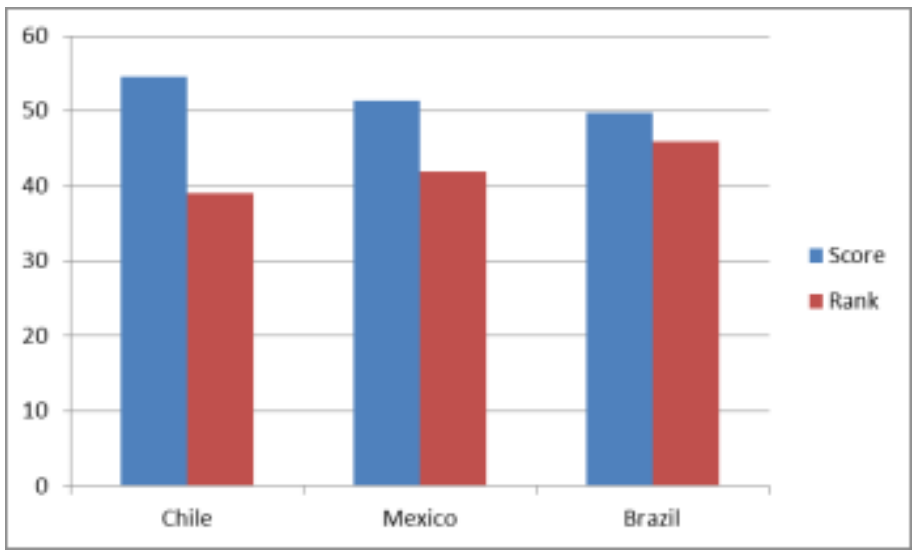

Figure 2: University /industry research collaboration (Source: Cornell University, INSEAD, and WIPO)

We use the average annual growth rate of patents by different time periods for selected countries. Figure 3 shows that Chile has had the highest growth rate of patents in the period 1980-2010, as well as in the other decades (except for the 2000s). Brazil has had growth rates below the Chilean patents. In the case of Mexico, in the eighties and nineties, it had negative rates of growth of patents, while in the 2000s it had a considerable increase in patents.

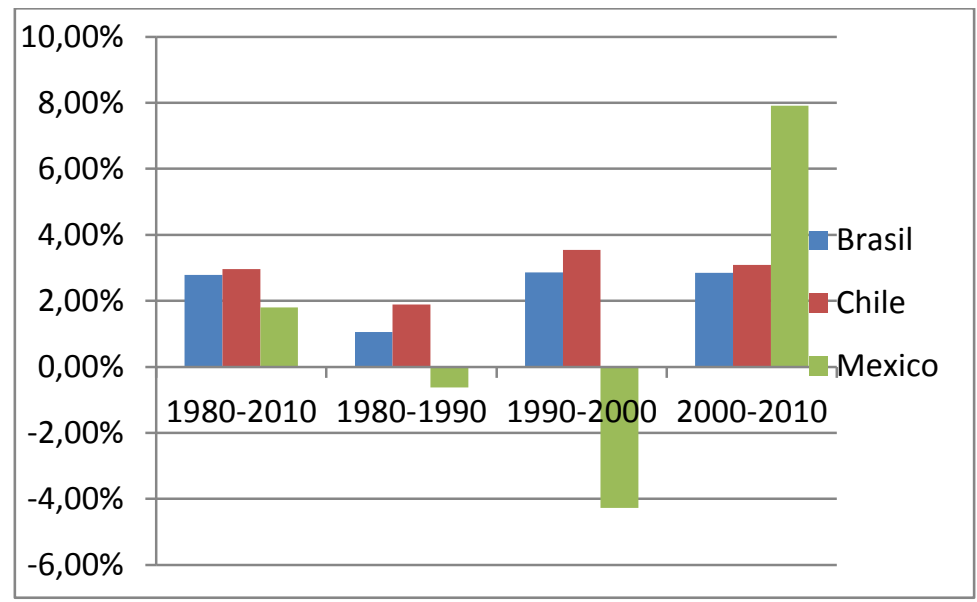

Figure 3: Patents average growth rate (per year) for selected countries (Source: World Development Indicators (World Bank))

Entrepreneurs stimulate innovation, because they turn inventions into innovations. Entrepreneurship, to encourage innovation, has a positive impact on economic growth, so that with the previous variable we explain the economic growth differentials between Chile and other countries.

Figure 4 shows the percentage of people aged 18 to 64 who tried to start a business in the last three years. Entrepreneurship in Chile has had a positive trend, because this variable has been increasing in recent years. The Chilean entrepreneurship is larger than that of Brazil and Mexico in almost all the data series. Only in 2005, Chile had a lower level of entrepreneurship than Brazil and Mexico. Moreover, entrepreneurship in all three countries decreased in 2005, and has subsequently increased in Chile and has stagnated in the other countries. 


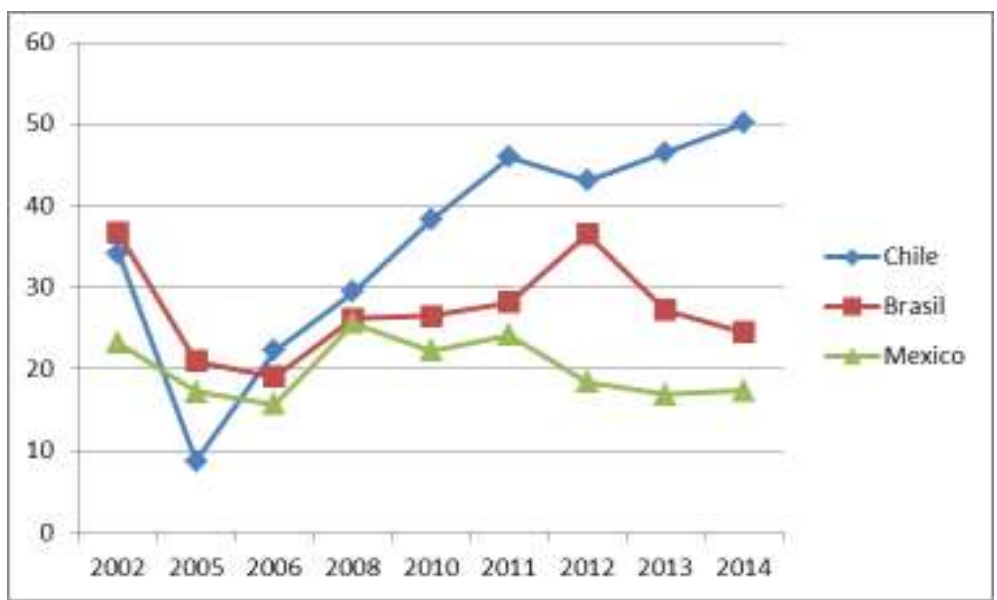

Figure 4: Percentage of 18-64 population who intend to start a business within three years, for selected countries

(Source: Global Entrepreneurial Monitor)

\section{Conclusion}

Chile's economic growth has been high in recent decades and is even comparable with countries that report higher economic growth in the world. On the other hand, Brazil and Mexico have an economic growth below the Chilean case, which led us to analyse the role of innovation in economic growth differentials across the three countries.

Using the variables of innovation for the three selected countries we found that the highest economic growth in Chile is explained by innovation and better conditions for creative destruction that exist in that country. Other variables that distinguish Chile from Brazil and Mexico, is the percentage of entrepreneurs, because there is a higher proportion of entrepreneurs in Chile.

The patent is one of the variables explaining economic growth. In the text we have found that the growth rate of the Chilean patent is greater than in the other selected countries. On the other hand, the level of entrepreneurship in Chile is higher than in Brazil and Mexico, i.e. in Chile there are better conditions for people who decide to start a new business. The variable used as a proxy of institutional gear, University / Industry research collaboration gave the expected results, because Chile has greater links between universities and industry favouring innovation.

Overall, the comparative analysis among Chile, Mexico and Brazil has shown that innovation is positively related to economic growth in the medium and long term. In the case of Chile, despite sharing many similarities with other countries, it has achieved high economic growth in the last three decades driven by innovation. Chile's spending on research and development (\% of GDP) is around 1\%, lower than the Brazilian, which shows that the links between innovation and economic growth are complex.

The analysis can be extended to all of Latin America, and it is even possible to measure econometrically the relationship between economic growth and some of the variables of innovation. However, the results obtained allow us to move forward in analysing the impact of innovation on economic growth.

\section{References}

- Acemoglu, D., Johnson, S., \& Robinson, J. A. (2005). Institutions as a fundamental cause of long-run growth. Handbook of economic growth, 1, pp. 385-472.

- Acosta, M. \& Coronado, D. (2006).Las relaciones ciencia - tecnología en Andalucía: Evidencia a partir de los documentos de patentes. Sevilla: Centro de EstudiosAndaluces.

- Aghion, P. \& R. Griffith (2008). Competition and Growth: Reconciling Theory and Evidence, Cambridge: The MIT Press.

- Aghion, P., \&Howitt, P. (1990).A model of growth through creative destruction. National Bureau of Economic Research No. w3223.

- Aghion, P., Bloom, N., Blundell, R., Griffith, R., \&Howitt, P. (2002). Competition and innovation: An inverted U relationship. National Bureau of Economic Research, No. w9269. 
- Barro, R. J. (1989). Economic growth in a cross section of countries. National Bureau of Economic Research No. w3120.

- Bizberg, I. (2015). Tipos de Capitalismo en América Latina In Bizberg, I. \& Bruno Théret (eds.) Variedades del capitalismo en América Latina: los casos de México, Brasil, Argentina y Chile. Distrito Federal: El Colegio de México. pp. 41-94.

- Casas, R., De Fuentes, C., Torres, A. \& O. Vera-cruz, A. (2013). Estrategias y gobernanza del Sistema Nacional Mexicano: retos para un desarrollo incluyente. In Dutrénit, G. \& Judith Sutz(eds.) Sistemas de Innovación para un desarrollo inclusivo: experiencia de Latinoamericana. Distrito Federal: Foro Consultativo Científico y Tecnológico.

- Cassiolato, J., Lastres, H. \&Soares, M. (2013). Sistema Nacional de Innovación de Brasil: Desafíos para la sostenibilidad y el desarrollo incluyente. In Dutrénit, G. \& Judith Sutz(eds.) Sistemas de Innovación para un desarrollo inclusivo: experiencia de Latinoamericana. Distrito Federal.: Foro Consultativo Científico y Tecnológico.

- Consejo Nacional para la Competitividad (2014). Informe del Consejo Nacional para la competitividad de Chile, http://www.compite.com.co/site/wp-content/uploads/2013/11/CPC_INC2013-2014-Informe.pdf. [accessed 05.02.2015].

- Cornell University, INSEAD, \& WIPO (2014). The Global Innovation Index 2014: The Human Factor In Innovation.Fontainebleau, Ithaca, and Geneva: Cornell University, INSEAD, and WIPO.

- Dossi, Freeman \& Nelson (1988).Technical Change and Economic Theory. Londres\& Nueva York: Pinter Publishers.

- Dutrenit

G. (1994). Sistema nacional de

http://revistas.bancomext.gob.mx/rce/magazines/362/1/RCE1.pdf [accessed 12.4.2015]

- Dutrénit, G. (2009). Sistemas Regionales de Innovación: un espacio para el desarrollo de las Pymes, http://csh.xoc.uam.mx/produccioneconomica/publicaciones/individuales/sistemas_regioales_de_innovacion.ht $\mathrm{ml}$ [accessed 12.4.2015]

- Edquist, C. \& Johnson, B. (1997). Institutions and organisations in systems of innovation. In Edquist, C. (ed.) Systems of Innovation: Technologies, Institutions and Organizations. London and Washington: Pinter/Cassell Academic.

- Feder, G. (1983).On exports and economic growth. Journal of development economics, 12(1), pp. 59-73.

- Fondo de Cooperación Internacional en Ciencia y Tecnología: Unión Europea - México (2010). Marco conceptual de la innovación en México, http://www.conacyt.gob.mx/siicyt/index.php/centros-deinvestigacion-conacyt/estadisticas-del-comite-tecnico-especializado/septima/1908--274/file. [accessed 05.02.2015].

- Freeman, C. (1993). El Reto de la Innovación. La Experiencia Japonesa. Caracas: Ed. Galac.

- Freeman, C. (2002). Continental, national and sub-national innovation systems - complementarity and economic growth. Research policy, 31(2), pp. 191-211.

- Galindo, M. (2012). La corriente del pensamiento neoschumpeteriana. Revista nuevas corrientes de pensamiento económico. No. 865.

- Gobierno de Chile, (2014). Sistema Nacional de Innovación 2010 - 2013: principales avances y hechos relevantes desde la politica pública, http://www.innovacion.gob.cl/wpcontent/uploads/2014/03/SistemaNacionalInnovacion.pdf [accessed 15.04.2015].

- Grossman, G.M. \& E. Helpman (1991). Innovation and Growth in the Global Economy, Cambridge: The MIT Press.

- Hanusch, H. \&Pyka, A. (2005).Principles of Neo-Schumpeterian Economics. Universität Augsburg, Augsburg, No. 278.

- Hanusch, H. \&Pyka, A. (2007).A Roadmap to Comprehensive Neo-Schumpeterian Economics. In Hanusch, H. \&Pyka, A. (eds): Elgar companion to neo-Schumpeterian economics. Cheltenham: Edward Elgar Publishing, pp. 1160-1170.

- Hodara, J. (2006). Entorno al sistema chileno de innovación científica y tecnológica: Apreciaciones crítica. Estudios interdisciplinarios de América Latina y del Caribe10( 1).

- Jiménez, F., Fernández, I. \&Menéndez, A. (2013). Los sistemasregionales de innovación: experiencias con cretasen América Latina. In Llisterry, J., Carlo Pietrobelli\& Mikael Larson (eds.) Los Sistemas Regionales de Innovación en América Latina. Washington, IADB. 
- Lundvall, B.(1992). ¿Porqué la nueva economía es una economía de aprendizaje?, http://www.littec.ungs.edu.ar/pdfespa\%F1ol/Cap1.\%20Lundvall.pdf[accessed 12.12.2014]

- Lundvall, B. A. (2009). Innovation as an interactive process: user-producer interaction to the national system of innovation: research paper. African journal of science, technology, innovation and development, 1(2 \& 3), pp. 10-34.

- Mahoney, P. G. (2001). The common law and economic growth: Hayek might be right. The Journal of Legal Studies, 30(2), pp. 503-525.

- Mankiw, N. G., Romer, D., \& Weil, D. N. (1990).A contribution to the empirics of economic growth.National Bureau of Economic Research No. 3541.

- Montoya, O. (2004). Schumpeter, innovación y determinismo tecnológico. RevistaScientia ET technica, No. 25.

- $\quad$ Mulder, K. (2007). Sustainable development for engineers. Barcelona: UPC.

- NESsT. (2012). Sistema Nacional de Innovación en Brasil y particularidadesdel sistema regional en el noreste: oferta y demanda por tecnología en ámbitos rurales, http://hdl.handle.net/10625/52668 [accessed 10.03.2014]

- North, D. C. (1989). Institutions and economic growth: A historical introduction. World development, 17(9), pp. 1319-1332.

- Organization for Economic Co-operation and Development (OECD) \& Development Statistical Office of the European Communities (Eurostat). (2014). Oslo Manual. Paris: OECD.

- Parraguez, P. (2009). Acerca del Sistema Nacional de Innovación: reflexiones y propuestas para el Chile del 2020, http://www.openinnovate.co.uk/papers/AcercadelSNI_PPR_24Sept09B.pdf [accessed 03.03.2015].

- $\quad$ Romer, Paul M. (1990).Endogenous Technological Change.Journal of Political Economy 98(5), pp. 71-102.

- Rincón, E. (2004). El Sistema nacional de innovación: Un análisis teórico- conceptual. Revista de Ciencias Humanas y Sociales, vol.20 (45).

- Romero, E. (2013). Interacción Universidad - Empresa: Políticas de innovación en Brasil y Chile, http://www.innovacion.gob.cl/2013/05/interaccion-universidad-empresa-politicas-de-innovacion-en-brasil-ychile/ [accessed 19.03.2015].

- Schneider, B. (2009). Hierarchical market economies and varieties of capitalism in Latin America. Journal of Latin American Studies 41 (03), pp. 553-575.

- Schumpeter, J. (1984).Capitalismo, Socialismo y Democracia. Barcelona: Ed.Folio.

- Scumpeter, J. (1994). Teoría del desenvolvimiento económico. D.F.: Fondo de Cultura Económica.

- Wong, P. K., Ho, Y. P., \&Autio, E. (2005). Entrepreneurship, innovation and economic growth: Evidence from GEM data. Small Business Economics, 24(3), pp. 335-350. 